\title{
마음수련명상의 지속기간에 따른 정신건강의 효과 Effects of Maum Meditation Training on Mental Health according to the Length of the Training Period
}

\author{
이인수 , 오진환 ${ }^{* *}$, 권인숙***
}

한국교통대학교 보건생명대학 응급구조학과*, 수원과학대학교 간호과**, 이화여자대학 부속고등학교 ${ }^{* * *}$

$$
\begin{array}{r}
\text { In-Soo Lee(islee7449@hanmail.net)*, Jin-Hwan Oh(ohjh37@hanmail.net) }{ }^{* *}, \\
\text { In-Sook Kwon(iskwon1@hanmail.net) }
\end{array}
$$

\section{요약}

본 연구는 마음수련명상의 지속기간에 따른 정신건강의 차이를 비교분석하기 위한 것이다. 단기집중 마 음수련명상의 효과를 파악하기 위한 단일군 전후 원시실험연구와 지속적 마음수련명상의 효과를 파악하기 위한 서술적 조사연구로 구성된다. 자료 수집 및 대상은 단기집중 마음수련명상군의 경우 2011년 7월 23일 부터 7월 30일, 2012년 1월 7일부터 1월 14일에 마음수련명상 프로그램에 참여한 교사들 75명을 대상으로 프로그램 실시 전후에 구조화된 설문지를 이용하여 자료 수집을 하였고, 지속적 마음수련명상군의 경우 2012년 2월 현재 마음수련명상을 1년 이상 지속한 교사들 101명을 대상으로 2012년 2월 15일에서 2월 28일 까지 자료 수집을 하였다. 자료 분석은 SPSS WIN 14.0 를 이용하였으며 연구결과는 다음과 같다. 단기집중 마음수련명상군의 경우 마음수련명상 전후에 정신건강의 모든 하위영역(신체화, 강박증, 대인예민성, 우울, 불안, 적대감, 공포불안, 편집증, 정신증)에서 유의한 차이가 있었다. 지속적 마음수련명상군의 지속기간에 따른 정신건강 정도는 편집증을 제외한 8개 영역(신체화, 강박증, 대인예민성, 우울, 불안, 적대감, 공포불안, 정신증)에서 모두 유의한 차이를 보였다. 결론적으로 마음수련명상이 단기적, 지속적 중재 모두에 효과가 있는 것으로 보아 임상에서의 단기적용과 스트레스 대처능력을 기르기 위한 지속적인 프로그램으로서 개발 과 적용이 필요하다.

\section{- 중심어 : | 명상 | 교사 | 정신건강 |}

\section{Abstract}

The purpose of this study was to investigate the effects of short-term Maum Meditation and to compare effects according to the length of the training period on mental health of teachers. In this research, 2 types of design were used which were one-group pre-posttest design and descriptive study. In short-term Maum Meditation group, 2 times of surveys were carried out, 75 teachers in the faculty training filled out the structured questionnaire. In Long-term Maum Meditation group, 101 teachers who were attending Maum Meditation above one-year filled out the structured questionnaire. The data were analyzed by SPSS WIN 14.0 program. The results showed that there was a significant difference in mental health including 9 subscales for short-term Maum Meditation group. Also, in long-term Maum Meditation group, there were significant differences in mental health excepting paranoid ideation. It was founded that Maum Meditation is the way for the mental health promotion in short - term and long-term period. So it is necessary to develop program according to training period for not only clinical application but also to strengthen coping ability for stress.

- keyword : | Meditation | Teacher | Mental Health |

\footnotetext{
*본 연구는 2012년도 한국교통대학교 교내학술연구비의 지원을 받아 수행한 연구임.

접수번호 : \#121119-001

접수일자 : 2012년 11월 19일

교신저자 : 오진환, e-mail : ohih37@hanmail.net
} 


\section{I. 서론}

\section{1. 연구의 필요성}

최근 들어 여러 연구들에서는 높은 수준의 불안과 우 울, 낮은 수준의 자존감 등 교사들의 심리적 디스트레 스가 유의하게 증가하고 있음을 보고하고 있고, 이는 곧 직무만족도에도 부정적인 영향을 줄 수 있는 것으로 나타났다[1-3]. 스페인 노동위원회(Labor Commissions) 의 보고에 따르면 여러 전문 직종 중 교사들은 스트레 스, 우울, 심리적 피로감의 정도가 심각하며 교사 10 명 중 8 명은 심리적 문제가 교사들의 주된 질환 중의 하나 라고 보고하고 있다[4].

스트레스는 인간의 신체 및 심리적 적응에 긍정적인 영향보다는 부정적인 영향요소로 알려져 있으며, 이러 한 부정적 영향에는 심장질환을 비롯한 정신신체질환 과 우울, 적대감, 불안 등의 심리적 부적응이 포함된다 [5]. 특히 교사들의 경우 반복적인 스트레스를 경험하게 되면 교사 개인의 정신, 신체 건강과 학교조직에 부정 적인 영향을 초래하며, 더 나아가 교사가 교육의 발전 에 기여할 수 없게 되어 교육력의 약화를 초래하여 결 과적으로 국가적인 큰 손실을 가져올 수 있다[2].

최근에 정신건강의 증진과 심리치료를 목적으로 한 명상프로그램이나 호흡법이 다양하게 활용되고 있는데 [6-9], 특히 명상을 통해서 마음이 편안해지면 개인이 가진 잠재력과 치유력이 잘 발휘될 수 있어 자기 자신 을 올바로 이해하게 되고 정신건강이 증진될 수 있다고 한다. 또한 명상을 하게 되면 자신의 왜곡된 생각을 바 로잡거나 감소시킬 수 있고, 자기와 세상을 있는 그대 로 올바로 보고 받아들이는데 도움이 되어 명상수행의 결과 개인의 고통이 줄어들고 긍정적 정서 함양에 도움 이 된다[6]. 이러한 명상의 잇점으로 불안, 우울 등의 심 리적 문제와 통증, 피부병 같은 신체적 증상 등 그 적용 범위가 확대되고 있다[9]. 의료영역 측면에서 볼 때 명 상은 서양의학과 함께 병행함으로써 상호보완을 이루 는 방법인 통합의학의 하나인 심신의학의 개념으로 이 용되고 있다. 우리나라의 경우 41 개 의과대학 중 약 35 여 개의 의과대학이 통합의학에 대한 교육을 실시하고 있다[10].
명상의 여러 유형[4][6-9][11][12]중 마음수련명상의 원리를 살펴보면, 마음은 자기라는 몸과 몸이 있어 살 아오면서 기억 및 무의식중에 기억된 일체의 생각이라 는 것이다. 이런 기억이 감정과 함께 영상으로 저장되 어 있어 사람의 마음과 행동에 지속적으로 영향을 미치 게 되는 것이다. 마음수련명상은 인간의 마음을 빼기하 여 우주마음으로 의식이 전환되는 8단계의 점진적 과 정으로 구성된 프로그램이다. 즉, 사람이 자기중심적이 고 허상인 자기만의 마음세계를 버리고, 세상의 근본인 우주마음으로 영원불변한 진리인 참마음으로 살도록 하는 방법이다[13].

서양의 인지상담과 마음수련명상에 대해 살펴보면 두 가지 방법 모두 대상자의 인식과 상황에 대한 수용 태도를 변화시키고 부정적인 정서를 감소시킨다는 유 사점이 있다[14]. 두 가지 방법의 차이점은 인지상담은 정서 발생의 원인을 인지 및 신념에 두고 있기 때문에 인지체계의 변화를 통하여 문제해결에 접근하는 반면 마음수련명상은 기억 속에 남아있는 감정을 직접 제거 함으로써 역기능적 사고의 발생조건을 없애어 문제해 결에 이를 수 있도록 도와준다는 점이라고 보여진다 [15]. 또한 마음수련명상은 본인의 마음상태를 다른 사 람에게 이야기하지 않고 각자의 산 삶의 기억을 스스로 버리게 되므로, 우리나라와 같이 정신건강에 사회적 편 견이 있는 문화 특성에 적합한 방법이라 하겠다. 현재 대구광역시 교육청에서 교직스트레스, 교권침해, 우울 증 등으로 고통 받는 교원에 대한 전문적인 상담과 치 료 지원 강화를 목적으로 하는 에듀힐링 프로그램에 마 음수련 프로그램이 교직스트레스 치유형 프로그램으로 운용되고 있다[16]. 김정호[17]도 명상을 하는 것은 자 기 스스로가 자기 자신에 대하여 상담가 혹은 심리치료 가가 되어 문제를 해결하고 성장해 가는 것으로 일종의 자가 상담 혹은 자가 심리치료라 하였다.

마음수련 명상과 관련된 선행연구들을 살펴보면 긍 정적 사고로의 관점변화[18],정신건강[7][19], 스트레스 와 직무만족도[20], 분노, 우울, 불안, 공격성 등의 정서 관련[14][21-23], 자존감 향상[14][19][24], 신체화 관련 [19], 인성지도[25]등 마음수련명상이 정신건강에 긍정 적 효과를 확인할 수 있다. 그러나 마음수련을 포함한 
대부분의 명상관련 연구들은 비동등성 대조군 전후차 이분석[4][6][8][11][26-30], 집단의 일반적 특성 내지는 중재방법에 따라 분류된 집단 간의 사전사후 비교 [7][14], 단일군 사전사후비교[19][23], 수행기간에 따른 사후-추수 효과성 입증[9][31], 서술적 조사연구[18][20] 등만 있을 뿐 명상의 지속시기에 따른 효과의 분석에 대한 연구는 거의 없는 실정이다.

따라서 본 연구에서는 1 주일 동안 마음수련명상 1 단 계 프로그램에 참여한 단기집중 마음수련명상군의 변 화를 확인하고, 1 년 이상 마음수련명상에 참여한 지속 적 마음수련 명상군에 있어 명상의 지속시기에 따른 효 과를 비교함으로써, 마음수련명상의 효과를 검증하고 자 한다. 그래서 향후 지역사회주민의 정신보건 향상을 위한 단기 및 장기 정신건강 프로그램으로써의 가능성 을 확인해 보고자 한다.

\section{2. 연구 문제}

본 연구는 마음수련명상이 교사의 정신건강에 미치 는 효과를 규명하여 정신건강 유지 및 증진을 위한 중 재전략으로 활용하기 위한 것이며 연구 문제는 다음과 같다.

첫째, 교사의 정신건강은 어떠한가?

둘째, 단기집중 마음수련명상은 교사의 정신건강에 어떤 영향을 미치는가?

셋째, 지속적 마음수련명상은 교사의 정신건강에 어 떤 영향을 미치는가?

\section{II. 연구 방법}

\section{1. 연구 설계}

본 연구는 마음수련명상이 교사의 정신건강에 미치 는 영향을 파악하기 위한 것으로 단기집중 마음수련명 상은 단일군 사전-사후 원시실험설계를 이용하였고, 지 속적 마음수련명상은 서술적 조사연구를 이용하였다.

\section{2. 연구 대상}

\section{1 단기집중 마음수련명상}

마음수련 교육원에서 1 주일 과정으로 진행된 교원자 율연수에 참여한 전국의 초, 중, 고등학교에 근무하는 교원으로 연구목적을 이해하고 연구에 참여하기를 허 락하고 충실하게 답한 교원 75 명이다.

\section{2 지속적 마음수련명상}

2003년 3월 이후 마음수련명상을 시작하여 2012년 2 월 현재 마음수련 지역교육원에서 1년 이상 마음수련 명상을 하고 있는 전국의 초, 중, 고등학교에 근무하는 교원으로 연구목적을 이해하고 연구에 참여하기를 허 락하고 충실하게 답한 교원 101 명이다.

\section{3. 연구 도구}

\section{1 마음수련명상}

마음수련명상은 살면서 쌓아온 자기라는 마음을 버 리고 본래의 마음자리, 즉 본성을 깨닫는 프로그램으로 지나간 산 삶의 기억을 탐색하여 버리는 것이 기본 원 리이다. 프로그램은 총 8단계 과정으로 구성되어 있으 며 교육과정은 [표 1]과 같다[32]. 본 연구에서 단기집 중마음수련명상은 마음수련명상 1 단계 과정이 적용되 었다. 마음수련명상은 [표 1]의 각 단계별 내용과 관련 된 기억을 떠올려 일정한 방법에 따라 마음으로 버리는 것이다.

\section{2 명상프로그램 효과 측정 도구}

\section{2 .1 정신건강}

본 연구에서는 Derogatia 등[33]이 개발한 도구를 김 재환 등[34]이 한국에 맞게 표준화한 간이정신건강진단 지(SCL-90)를 사용하였다. 정신건강은 신체화, 강박증, 대인예민성, 우울, 불안, 적대감, 공포불안, 편집증, 정신 증의 9 가지 하위요인으로 구성되어 있다. 총 90 문항의 5점 척도로 구성되었으며, '전적으로 동의 안함'을 0 점, '전적으로 동의함’을 4점으로 한다. 점수는 4점 만점이 며, 점수가 높을수록 정신건강이 낮은 것으로 평가된다. 배행자[35]의 연구에서의 Cronbach's alpha는 .92, 정혜 선과 송은주[36]의 연구에서의 Cronbach's alpha는 .87 로 나타났다. Derogatia 등[33]이 개발한 도구에서의 하 위영역별 Cronbach's alpha는 .77-.90이었다. 본 연구에 
표 1. 마음수련명상의 단계별 목표와 내용

\begin{tabular}{|l|l|l|}
\hline \multicolumn{1}{|c|}{ 단곅표 } & \multicolumn{1}{|c|}{ 내용 } \\
\hline 1단계 & 나의 본성이 우주임 알기 & 산 삶의 기억된 생각 버리기 \\
\hline 2단계 & 마음없음 알기 & 자기의 상과 인연의 상과 자기 버리기 \\
\hline 3단계 & 내 안에 우주 있음 알기 & 마음으로 몸이라는 인식 버리기 \\
\hline 4단계 & 본정신 알기 & 나와 우주 버리기 \\
\hline 5단계 & 본정신과 본정신의 나라 알기 & 나와 우주 버리기 \\
\hline 6단계 & 본정신 되는 과정 & 자기가 블랙홀로 들어가서 녹아 없어져서 우주되기 \\
\hline 7단계 & 허상세계 총정리 과정 & 허상세계 전체와 나 부수기 \\
\hline 8단계 & 진리로 거듭나 진리 삶 살기 & 다 없애어 진리로 거듭나 진리 행하기 \\
\hline
\end{tabular}

서 정신건강의 Cronbach's alpha는 .98로 나타났으며, 대상자에 따른 하위요인의 Cronbach's alpha는 [표 2] 와 같다.

표 2. 정신건강 하위변인의 신뢰도 수준

\begin{tabular}{|c|c|c|c|}
\hline \multirow{2}{*}{ 하위요인 } & \multirow{2}{*}{ 문항수 } & \multicolumn{2}{|c|}{ Cronbach's alpha } \\
\cline { 3 - 4 } & & 단기집중 마음수련 & 지속적 마음수련 \\
\hline \multirow{2}{*}{ 신체화 } & 12 & .90 & .88 \\
강박증 & 10 & .88 & .90 \\
대인예민성 & 9 & .88 & .93 \\
우울 & 13 & .94 & .91 \\
불안 & 10 & .92 & .92 \\
적대감 & 6 & .89 & .85 \\
공포불안 & 7 & .85 & .85 \\
편집증 & 6 & .85 & .80 \\
정신증 & 10 & .88 & .88 \\
\hline & & & .99 \\
\hline 전 체 & 90 & .98 & \\
\hline
\end{tabular}

\section{4. 프로그램 운영}

마음수련명상 프로그램은 강의와 명상으로 이루어졌 으며, 강의의 내용에는 마음의 정의, 마음수련명상의 목 적, 마음수련명상 방법 등에 대한 내용으로 구성되어 실시되었다.

단기집중 마음수련명상군의 경우 마음수련 교육원에 서 마음수련 교육원 전문 강사들이 진행하였다. 구체적 인 진행 프로그램은 [표 3]과 같다. 지속적 마음수련명 상군의 경우 마음수련 지역수련원에서 지역수련원 전 문 강사들이 진행하는 [표 1]에 제시된 내용의 프로그 램으로 마음수련명상을 하고 있다.

표 3. 단기집중 마음수련명상 교원연수 프로그램

\begin{tabular}{|c|c|c|c|c|c|c|c|c|}
\hline 시 간 & 1일차 & 2일차 & 3일차 & 4일차 & 5일차 & 6일차 & 7일차 & 8일차 \\
\hline $\begin{array}{l}09: 00 \quad- \\
10: 30\end{array}$ & & 강의 2 & 강의 4 & 강의 6 & 강의 8 & 강의 10 & 강의 12 & $\begin{array}{c}\text { 버려진 } \\
\text { 마음 확인 }\end{array}$ \\
\hline \multirow{2}{*}{$\begin{array}{l}11: 00 \\
12: 20\end{array}$} & & \multirow{2}{*}{$\begin{array}{c}\text { 실기 } \\
\text { (마음버리기- } \\
\text { 나이순 I) }\end{array}$} & \multirow{2}{*}{$\begin{array}{c}\text { 실기 } \\
\text { (마음버리기- } \\
\text { 가족관계) }\end{array}$} & \multirow{2}{*}{$\begin{array}{c}\text { 실기 } \\
\text { (마음버리기- } \\
\text { 지도학생에 } \\
\text { 관한 기억) } \\
\end{array}$} & \multirow{2}{*}{$\begin{array}{c}\text { 실기 } \\
\text { (마음버리기- } \\
\text { 틀깨기) }\end{array}$} & \multirow{2}{*}{$\begin{array}{c}\text { 실기 } \\
\text { (마음버리기- } \\
\text { 직장동료 } \\
\text { 및 친구) }\end{array}$} & \multirow{2}{*}{$\begin{array}{c}\text { 실기 } \\
\text { (마음버리기- } \\
\text { 학교업무 } \\
\text { 관련갈등) }\end{array}$} & 강의 14 \\
\hline & & & & & & & & 수료식 \\
\hline \multicolumn{9}{|l|}{$\begin{array}{l}12: 20 \\
13: 50\end{array}$} \\
\hline \multirow{2}{*}{$\begin{array}{l}14: 00 \\
15: 30\end{array}$} & & 강의 3 & 강의 5 & 강의 7 & 강의 9 & 강의 11 & \multirow{3}{*}{$\begin{array}{c}\text { 실기 } \\
\text { (마음버리기 - } \\
\text { 보고 배운 } \\
\text { 내용 전체) }\end{array}$} & \\
\hline & 개강식 & \multirow{2}{*}{$\begin{array}{c}\text { 실기 } \\
\text { (마음버리기- } \\
\text { 나이순II) }\end{array}$} & \multirow{2}{*}{$\begin{array}{c}\text { 실기 } \\
\text { (마음버리기- } \\
\text { 친인척관계) }\end{array}$} & \multirow{2}{*}{$\begin{array}{c}\text { 실기 } \\
\text { (마음버리기- } \\
\text { 학생시절기억) }\end{array}$} & \multirow{2}{*}{$\begin{array}{c}\text { 실기 } \\
\text { (마음버리기- } \\
\text { 나이순 }\end{array}$} & \multirow{2}{*}{$\begin{array}{c}\text { 실기 } \\
\text { (마음버리기- } \\
\text { 지도학생에 } \\
\text { 관한 기억) }\end{array}$} & & \\
\hline $\begin{array}{l}16: 00 \\
17: 30\end{array}$ & 강의 1 & & & & & & & \\
\hline $\begin{array}{ll}17: 30 \quad- \\
19: 30\end{array}$ & & & & & & & & \\
\hline $\begin{array}{l}19: 30 \\
21: 00\end{array}$ & \multirow{2}{*}{$\begin{array}{c}\text { 실기 } \\
\text { (기억 } \\
\text { 떠올리기) }\end{array}$} & \multirow{2}{*}{$\begin{array}{c}\text { 실기 } \\
\text { (마음버리기- } \\
\text { 나이순 II) }\end{array}$} & \multirow{2}{*}{$\begin{array}{c}\text { 실기 } \\
\text { (마음버리기- } \\
\text { 친구 및 } \\
\text { 직장동료) }\end{array}$} & \multirow{2}{*}{$\begin{array}{c}\text { 실기 } \\
\text { (마음버리기- } \\
\text { 학생지도방식) }\end{array}$} & \multirow{2}{*}{$\begin{array}{c}\text { 실기 } \\
\text { (마음버리기- } \\
\text { 가족 및 } \\
\text { 친인척) }\end{array}$} & \multirow{2}{*}{$\begin{array}{c}\text { 실기 } \\
\text { (마음버리기- } \\
\text { 학생지도방식) }\end{array}$} & $\begin{array}{c}\text { 버려진 } \\
\text { 마음확인 }\end{array}$ & \\
\hline $\begin{array}{l}21: 30 \\
23: 00\end{array}$ & & & & & & & 강의 13 & \\
\hline
\end{tabular}




\section{5. 자료 수집}

자료 수집은 단기집중 마음수련 명상군의 경우 2011 년 7월 23일부터 7월 30일, 2012년 1월 7일부터 1월 14 일까지 이었다. 사전조사의 자료 수집은 명상프로그램 을 실시하기 전 1 일차에 제 1 실험군과 제 2 실험군 모 두 동일한 내용으로 실시하였다. 사후조사의 자료 수집 은 명상프로그램을 모두 진행한 후에 사전조사와 동일 한 방법으로 실시하였다. 지속적 마음수련 명상군의 경 우 자료 수집은 2012년 2월 15일에서 2월 28일에 실시되 었다.

\section{6. 자료 분석}

본 연구에서 수집된 자료는 SPSS/WIN 14.0 프로그 램을 이용하여 분석하였다. 대상자의 일반적 특성, 직업 관련 특성 및 마음수련명상기간은 실수와 백분율을 사 용하였다. 교사의 정신건강 정도는 평균과 표준편차를 이용하였다. 단기집중 마음수련명상이 교사의 정신건 강에 미치는 효과를 확인하기 위해 paired t-test를 사 용하였다. 지속적 마음수련 명상이 교사의 정신건강에 미치는 효과를 확인하기 위해 일원분산분석을 사용하 였고, 통계적으로 유의한 항목의 사후분석은 Scheffe's test를 실시하였다.

\section{III. 연구결과}

\section{1. 연구대상자의 일반적 특성}

\section{1 단기집중 마음수련 명상군}

대상자는 여성이 $70.7 \%$, 남성이 $29.3 \%$ 이었으며, 연령 은 35-44세가 33.3\%, 45-54세가 31.4\%이었다. 학력은 석사이상이 $57.4 \%$, 배우자는 있는 경우가 $79.7 \%$, 종교 는 없음이 $56.0 \%$ 로 많았다. 학교 급별은 초등학교 $47.4 \%$, 고등학교 $34.2 \%$ 의 순이었으며, 교직경력은 20-30년 미만이 31.0\%, 10년 미만이 29.7\%로 나타났다. 인지된 건강상태는 보통이다로 응답한 경우가 $41.3 \%$, 직무만족 수준은 보통이다로 응답한 경우가 $48.0 \%$ 로 가장 많았다[표 4].

\section{2 지속적 마음수련 명상군}

대상자는 여성이 $88.1 \%$, 남성이 $11.9 \%$ 이었으며, 연 령은 45-54세가 40.6\%, 35-44세가 38.6\%이었다. 학력 은 대졸이하가 $65.3 \%$, 배우자는 있는 경우가 $69.3 \%$, 종 교는 없음이 $84.7 \%$ 로 많았다. 학교 급별은 초등학교 $47.9 \%$, 고등학교 $31.3 \%$ 의 순이었으며, 교직경력은 10-20년 미만이 35.6\%, 20-30년 미만이 32.7\%로 나타 났다. 인지된 건강상태는 건강하다로 응답한 경우가 $64.4 \%$, 직무만족 수준은 만족한다로 응답한 경우가 $75.0 \%$ 로 가장 많았다. 마음수련명상 지속기간은 7년 이 상 $32.7 \%, 1-3$ 년 미만 28.7\%의 순이었다[표 4].

표 4. 대상자의 일반적 특성 및 직업관련 특성

$\mathrm{N}=176$

\begin{tabular}{|c|c|c|c|}
\hline & 요인 & $\begin{array}{c}\begin{array}{c}\text { 단기집중 명상군 } \\
(n=75)\end{array} \\
\end{array}$ & $\begin{array}{c}\begin{array}{c}\text { 지속적 명상군 } \\
(n=101)\end{array} \\
\end{array}$ \\
\hline & & $\mathrm{n}(\%)$ or $\mathrm{M} \pm \mathrm{SD}$ (range) & $\mathrm{n}(\%)$ or $\mathrm{M} \pm \mathrm{SD}$ (range) \\
\hline 성별 & $\begin{array}{l}\text { 남 } \\
\text { 여 }\end{array}$ & $\begin{array}{l}22(29.3) \\
53(70.7) \\
\end{array}$ & $\begin{array}{l}12(11.9) \\
89(88.1) \\
\end{array}$ \\
\hline 나이(age) & $\begin{array}{l}\text { 34세 이하 } \\
\text { 35-44세 이하 } \\
\text { 45-54세 이하 } \\
\text { 55세 이상 }\end{array}$ & $\begin{array}{c}42.72 \pm 9.62(26 \sim 62 \text { 세) } \\
18(24.0) \\
25(33.3) \\
24(31.4) \\
10(13.3) \\
\end{array}$ & $\begin{array}{c}42.65 \pm 7.76(23 \sim 61 \text { 세) } \\
17(16.8) \\
39(38.6) \\
41(40.6) \\
4(4.0) \\
\end{array}$ \\
\hline 배우자유무 & $\begin{array}{l}\text { 없음 } \\
\text { 있음 }\end{array}$ & $\begin{array}{l}15(20.3) \\
59(79.7) \\
\end{array}$ & $\begin{array}{l}31(30.7) \\
70(69.3) \\
\end{array}$ \\
\hline 학력 & $\begin{array}{l}\text { 대졸 이하 } \\
\text { 석사 이상 }\end{array}$ & $\begin{array}{l}32(42.7) \\
43(57.4) \\
\end{array}$ & $\begin{array}{l}66(65.3) \\
35(34.7) \\
\end{array}$ \\
\hline 종교 & $\begin{array}{l}\text { 있음 } \\
\text { 없음 } \\
\end{array}$ & $\begin{array}{l}33(44.0) \\
42(56.0)\end{array}$ & $\begin{array}{l}15(15.3) \\
83(84.7)\end{array}$ \\
\hline
\end{tabular}




\begin{tabular}{|ll|c|c|}
\hline 교직경력(year) & 10년 미만 & $16.76 \pm 10.41(12 \sim 497$ 개월) & $17.24 \pm 8.26(12 \sim 420$ 개월) \\
& 10-20년 미만 & $22(29.7)$ & $23(22.8)$ \\
& 20-30년 미만 & $20(27.1)$ & $36(35.6)$ \\
& 30년 이상 & $23(31.0)$ & $9(32.7)$ \\
& 초등학교 & $9(12.2)$ & $47(47.4)$ \\
\hline 학교급별 & 중학 & $35(47.9)$ & $21(21.2)$ \\
& 고등학교 & $13(17.8)$ & $31(31.3)$ \\
& 건강 & $25(34.2)$ & $65(64.4)$ \\
인지된 & 보통 & $26(34.7)$ & $27(26.7)$ \\
건강상태 & 건강하지 않음 & $31(41.3)$ & $9(8.9)$ \\
\hline 직무만족 수준 & 만족 & $18(24.0)$ & $75(75.0)$ \\
& 보통 & $30(40.0)$ & $17(17.0)$ \\
& 만족하지 않음 & $36(48.0)$ & $8(8.0)$ \\
\hline 명상기간 & 1-3년 미만 & $9(12.0)$ & $290(28.7)$ \\
& 3-5년 미만 & & $20(19.8)$ \\
& 5-7년 미만 & & $19(18.8)$ \\
& 7년 이상 & & $33(32.7)$ \\
\hline
\end{tabular}

\section{2. 단기집중 마음수련명상이 교사의 정신건강에 미치는 효과}

\section{1 대상자의 정신건강정도}

단기집중 마음수련명상에 참여한 교사의 정신건강 정도를 측정한 결과는 [표 5]와 같다. 대상자의 정신건 강은 0.87 점(3점 만점)이었다. 하위영역별 정신건강 정 도는 3 점 만점에 신체화는 0.75 점, 강박증은 1.16 점, 대 인예민성은 1.04 점, 우울은 1.18 점, 불안은 0.84 점, 적대 감은 0.76 점, 공포불안은 0.38 점, 편집증은 0.70 점, 정신 증은 0.71 점이었다.

표 5. 대상자의 정신건강 정도

$\mathrm{N}=75$

\begin{tabular}{|c|c|}
\hline 요인 & 평균(표준편차) \\
\hline 정신건강 & $0.87(.62)$ \\
신체화 & $0.75(.67)$ \\
강박증 & $1.16(.72)$ \\
대인예민성 & $1.04(.69)$ \\
우울 & $1.18(.85)$ \\
불안 & $0.84(.77)$ \\
적대감 & $0.76(.79)$ \\
공포불안 & $0.38(.54)$ \\
편집증 & $0.70(.65)$ \\
정신증 & $0.71(.63)$ \\
\hline
\end{tabular}

\section{2 단기집중 마음수련명상이 정신건강에 미치는 효과}

단기집중 마음수련명상 전과 후의 교사의 정신건강 의 비교는 [표 6]과 같다. 단기집중 마음수련명상 전 전 체 정신건강 점수는 $.87 \pm .62$ 점에서 단기집중 마음수련
명상 후 전체 $.38 \pm .45$ 점으로 유의하게 감소하였으며 $(\mathrm{p}<0.001)$, 정신건강의 하위요소인 신체화 $(\mathrm{t}=6.53$, $\mathrm{p}<0.001)$, 강박증 $(\mathrm{t}=8.15, \mathrm{p}<0.001)$, 대인예민성 $(\mathrm{t}=8.45$, $\mathrm{p}<0.001)$, 우울 $(\mathrm{t}=8.91, \mathrm{p}<0.001)$, 불안 $(\mathrm{t}=7.15, \mathrm{p}<0.001)$, 적대감 $(\mathrm{t}=7.37, \mathrm{p}<0.001)$, 공포불안 $(\mathrm{t}=4.59, \mathrm{p}<0.001)$, 편 집증 $(\mathrm{t}=6.77, \mathrm{p}<0.001)$, 정신증 $(\mathrm{t}=6.74, \mathrm{p}<0.001)$ 에서 모 두 통계학적으로 유의한 감소가 나타났다 $(\mathrm{p}<0.001)$.

\section{표 6. 단기집중 마음수련명상이 교사의 정신건강에 미치는} 효과

$\mathrm{N}=75$

\begin{tabular}{|c|c|c|c|c|}
\hline \multirow{2}{*}{ 요인 } & 마음수련 전 & 마음수련 후 & \multirow{2}{*}{$t$} & $p$ \\
\cline { 2 - 3 } & 평균(표준편차) & 평균(표준편차) & & \\
\hline 정신건강 & $0.87(.62)$ & $0.38(.45)$ & 8.82 & $<0.001$ \\
신체화 & $0.75(.67)$ & $0.36(.43)$ & 6.53 & $<0.001$ \\
강박증 & $1.16(.72)$ & $0.57(.61)$ & 8.15 & $<0.001$ \\
대인예민성 & $1.04(.69)$ & $0.47(.52)$ & 8.45 & $<0.001$ \\
우울 & $1.18(.85)$ & $0.46(.59)$ & 8.91 & $<0.001$ \\
불안 & $0.84(.77)$ & $0.32(.50)$ & 7.15 & $<0.001$ \\
적대감 & $0.76(.79)$ & $0.25(.43)$ & 7.37 & $<0.001$ \\
공포불안 & $0.38(.54)$ & $0.18(.38)$ & 4.59 & $<0.001$ \\
편집증 & $0.70(.65)$ & $0.28(.44)$ & 6.77 & $<0.001$ \\
정신증 & $0.71(.63)$ & $0.31(.50)$ & 6.74 & $<0.001$ \\
\hline
\end{tabular}

\section{3. 지속적 마음수련명상이 교사의 정신건강에 미}

\section{치는 효과}

마음수련명상 지속기간에 따른 교사의 정신건강의 차이를 분석한 결과는 [표 7]과 같다. 전체 정신건강 $(\mathrm{F}=6.004, \mathrm{p}=.001)$, 신체화 $(\mathrm{F}=6.032, \mathrm{p}=.001)$, 강박증 $(\mathrm{F}=6.420, \mathrm{p}=.001)$, 대인예민성 $(\mathrm{F}=3.406, \mathrm{p}=.021)$, 우울 


\begin{tabular}{|c|c|c|c|c|c|}
\hline 변수 & 구분 & 평균(표준편차) & $\bar{F}$ & $p$ & post hoc test \\
\hline \multirow{4}{*}{ 정신건강 } & 1-3년 미만 ${ }^{a}$ & $0.61(.10)$ & \multirow{4}{*}{6.004} & \multirow{4}{*}{.001} & \multirow{4}{*}{$a>b, c, d$} \\
\hline & 3-5년 미만 & $0.27(.24)$ & & & \\
\hline & 5-7년 미만 & $0.27(.33)$ & & & \\
\hline & 7년 이상 & $0.27(.24)$ & & & \\
\hline \multirow{4}{*}{ 신체화 } & 1-3년 미만 ${ }^{a}$ & $0.51(.49)$ & \multirow{4}{*}{6.032} & \multirow{4}{*}{.001} & \multirow{4}{*}{ a)c,d } \\
\hline & 3-5년 미만 ${ }^{b}$ & $0.26(.26)$ & & & \\
\hline & 5-7년 미만 ${ }^{\mathrm{c}}$ & $0.20(.26)$ & & & \\
\hline & 7년 이상 & $0.19(.20)$ & & & \\
\hline \multirow{4}{*}{ 강박증 } & 1-3년 미만 ${ }^{a}$ & $0.89(.67)$ & \multirow{4}{*}{6.420} & \multirow{4}{*}{.001} & \multirow{4}{*}{$a>b, c, d$} \\
\hline & 3-5년 미만 ${ }^{b}$ & $0.47(.41)$ & & & \\
\hline & 5-7년 미만 & $0.37(.45)$ & & & \\
\hline & 7년 이상 & $0.42(.36)$ & & & \\
\hline \multirow{4}{*}{ 대인예민성 } & 1-3년 미만 & $0.84(.91)$ & \multirow{4}{*}{3.406} & \multirow{4}{*}{.021} & \multirow{4}{*}{$a>b, c, d$} \\
\hline & 3-5년 미만 ${ }^{b}$ & $0.41(.34)$ & & & \\
\hline & 5-7년 미만 & $0.42(.54)$ & & & \\
\hline & 7년 이상 ${ }^{d}$ & $0.43(.33)$ & & & \\
\hline \multirow{4}{*}{ 우울 } & 1-3년 미만 ${ }^{a}$ & $0.76(.64)$ & \multirow{4}{*}{4.416} & \multirow{4}{*}{.006} & \multirow{4}{*}{$a) b, d$} \\
\hline & 3-5년 미만 & $0.35(.33)$ & & & \\
\hline & 5-7년 미만 & $0.38(.48)$ & & & \\
\hline & 7년 이상 & $0.40(.38)$ & & & \\
\hline \multirow{4}{*}{ 불안 } & 1-3년 미만 ${ }^{a}$ & $0.52(.53)$ & \multirow{4}{*}{5.607} & \multirow{4}{*}{.001} & \multirow{4}{*}{$a>b, c, d$} \\
\hline & 3-5년 미만 ${ }^{b}$ & $0.20(.25)$ & & & \\
\hline & 5-7년 미만 & $0.19(.30)$ & & & \\
\hline & 7년 이상 & $0.19(.27)$ & & & \\
\hline \multirow{4}{*}{ 적대감 } & 1-3년 미만 & $0.49(.47)$ & \multirow{4}{*}{5.695} & & \\
\hline & 3-5년 미만 ${ }^{b}$ & $0.14(.20)$ & & & \\
\hline & 5-7년 미만 ${ }^{\mathrm{C}}$ & $0.23(.43)$ & & .001 & $a>b, d$ \\
\hline & 7년 이상 & $0.16(.26)$ & & & \\
\hline & 1-3년 미만 & $0.35(.50)$ & & & \\
\hline & 3-5년 미만 ${ }^{b}$ & $0.12(.19)$ & & & \\
\hline 공포불안 & 5-7년 미만 ${ }^{\mathrm{C}}$ & $0.05(.09)$ & 5.915 & .001 & a)b,d \\
\hline & 7 년 이상 & $0.08(.13)$ & & & \\
\hline & 1-3년 미만a & $0.49(.53)$ & & & \\
\hline & 3-5년 미만 & $0.21(.29)$ & & & \\
\hline 편집승 & 5-7년 미만 & $0.33(.55)$ & 1.720 & .168 & N.S. \\
\hline & 7년 이상 & $0.31(.36)$ & & & \\
\hline & 1-3년 미만a & $0.50(.57)$ & & & \\
\hline & 3-5년 미만 ${ }^{b}$ & $0.18(.22)$ & & & \\
\hline 정신증 & 5-7년 미만 & $0.17(.29)$ & 5.141 & .002 & $a\rangle b, c, d$ \\
\hline & 7년 이상 & $0.18(.25)$ & & & \\
\hline
\end{tabular}

$(\mathrm{F}=4.416, \mathrm{p}=.006), \quad$ 불안 $(\mathrm{F}=5.607, \mathrm{p}=.001)$, 적대감 $(\mathrm{F}=5.695, \mathrm{p}=.001)$, 공포불안 $(\mathrm{F}=5.915, \mathrm{p}=.001)$, 정신증 $(\mathrm{F}=5.141, \mathrm{p}=.002)$ 에서 통계적으로 유의한 차이가 나타 났으며, 편집증만이 통계적으로 유의하지 않은 것으로 나타났다 $(\mathrm{F}=1.720, \mathrm{p}=.168)$. 사후검정 결과 전체 정신건 강, 강박증, 불안, 정신증 정도는 1-3년 미만 집단과 3-5 년 미만, 5-7년 미만, 7년 이상 집단 간에 유의한 차이 가 있었다. 적대감, 공포불안, 우울 정도는 1-3년 미만 집단과 3-5년 미만, 7 년 이상 집단 간에 유의한 차이가
있었으며, 신체화 정도는 1-3년 미만 집단과 5-7년 미 만, 7년 이상 집단 간에 유의한 차이가 있었다.

\section{IV. 논의 및 결론}

본 연구는 교사를 대상으로 하여 마음수련 명상의 수 련기간에 따른 정신건강의 차이를 비교분석 하였다. 즉, 단기집중 명상군은 마음수련 명상 중재 전과 후의 정신 
건강정도 차이를 비교분석하였고, 지속적 명상군은 지 속기간에 따른 정신건강정도의 차이를 조사 분석하였 다. 그 결과는 다른 연구와 마찬가지로 명상이 정신건 강에 긍정적 효과가 있는 것으로 확인되었다.

본 연구에서 교사의 정신건강정도 점수는 0.87 점(점 수범위0-4점)으로 대체적으로 낮아 정신적 건강이 비 교적 양호한 것으로 나타났다. 본 연구대상자들의 정신 건강 하위영역별 점수와 김재환 등[34]이 한국인에 맞 게 표준화 한 간이정신진단 검사지 $(\mathrm{SCL}-90-\mathrm{R})$ 의 개발 당시 정상인 집단을 대상으로 조사한 결과를 비교해 볼 때 9 개 하위영역 중 대인예민성, 우울, 정신증의 3 개 영 역에서 디스트레스 정도가 일반인보다 높게 나타났다. 반면 6 개 하위영역인 신체화, 강박증, 불안, 적대감, 공 포불안, 편집증 정도는 일반 성인에 비해 정신건강 정 도가 더 좋은 것으로 나타났다.

하위요인별 통계결과를 비교해 보면 우울(1.18점), 강 박증(1.16점), 대인예민성(1.04점)의 점수가 높아 상대 적으로 다른 하위요인에 비해 정신건강이 좋지 않은 것 으로 나타났는데 이는 김재환 등[34]이 일반성인의 경 우 강박증(1.17점), 대인예민성(1.00점), 우울(0.98점) 점 수가 높다고 보고한 것과 비슷한 결과이다. 하지만 대 학생 집단에서는 대인예민성(53.3점), 편집증(52.3점), 적개심(52.0점), 강박증(50.0점)이 높게 나타났으며[6], 군인 집단에서 신체화(52.5점), 공포불안(52.0점), 불안 (51.2점), 대인예민성(51.2점), 우울(50.8점), 강박증(50.7 점)이 높게 나타난 결과[36]를 볼 때 하위영역별 점수 순위에서는 약간의 차이가 있으나 점수가 높은 하위영 역들은 대체로 비슷한 것을 볼 수 있다. 이 결과는 지역 사회 주민을 대상으로 정신건강 유지 및 증진 전략을 수립할 때에 강박증, 대인예민성 및 우울 등에 특히 유 의해야 할 것이라는 점을 시사한다.

한편 단기집중 마음수련 명상군의 중재 후 정신건강 은 중재 전 0.87 점에서 중재 후 0.38 점으로 유의하게 감 소하였으며, 하위요인인 신체화, 강박증, 대인예민성, 우울, 불안, 적대감, 공포불안, 편집증, 정신증의 9 개 영 역 모두에서 유의한 차이를 보였다. 이 결과를 명상방 법과 기간은 다양하지만 동일 측정도구를 이용한 다른 연구와 비교해 보고자 한다. 본 연구결과는 교사를 대
상으로 Flow Meditation을 주 1회 10주간 10회기를 실 시한 Clemento등[4]의 연구에서도 9개 하부영역 모두 에서 유의한 전후 차이가 있는 것으로 나타난 결과와, 일반인을 대상으로 1 주일의 마음수련명상 중재 후 9 개 하부영역 모두에서 유의한 차이를 보인 선행연구[19] 결과와 일치한다. 또한 대학생에게 8회기의 감정표현에 기반을 둔 명상프로그램을 중재한 결과 7 개 하부영역 인 신체화, 강박증, 우울, 불안, 적대감, 편집증, 정신증 에서 집단 간 유의한 차이가 있는 것으로 나타난 연구 [8], 간호학생을 대상으로 오중유식관을 적용한 연구에 서 7 개 하부영역인 강박증, 대인예민성, 우울, 불안, 적 대감, 편집증, 정신증에서 유의한 차이가 있는 것으로 나타난 결과[12], 중년 여성을 대상으로 8회기의 마음챙 김명상을 중재한 연구에서 4 개 하부영역인 신체화, 우 울, 불안, 적대감에서 유의한 차이가 있는 것[26]과 일 반인과 대학원생을 대상으로 마음챙김명상 중재결과 7 개 하부영역인 신체화, 대인예민성, 우울, 적대감, 편집 증, 정신증 영역에서 유의한 차이가 있는 것으로 나타 난 선행 연구[37] 결과와는 일부 차이가 있다. 추후 다 양한 명상방법을 이용하여 효과의 차이를 비교, 파악하 는 연구과정이 필요하다 하겠다.

이외에도 정신건강을 측정하는 척도는 다르지만 6-8회의 명상 중재 후 불안감소를 보고한 연구들 [23][27][28][38], 우울감소를 보고한 연구들[39-43], 공 격성, 분노와 신체화 증상 감소를 보고한 연구들 [19][44],정서와 관련하여 긍정적인 개선을 가져왔음을 보고한 연구들[9][31][45][46], 스트레스 개선을 보고한 연구[11][29]들은 단기간의 명상이 정신건강에 효과적 이라는 본 연구결과를 지지하고 있다.

본 연구가 단기간의 중재임에도 불구하고 모든 하위 영역에서 유의한 차이가 나타난 것은 마음수련명상 1 단계 과정은 자신의 본성을 알게 되는 단계인데 인간마 음을 버려 본래 우주가 나임을 알게 되므로 '나'라는 것 에 대한 관점이 근본적으로 변화하기 때문이다. 또한 개체 의식수준에서 전체적인 우주적 수준으로의 의식 전환을 경험하게 되기 때문이다[19]. 최연자[39]도 명칭 과 사물의 본질을 자각하게 하는 우울과 스트레스 사건 에 대한 본질직관 명상요법의 중재는 의식의 주체를 이 
루는 뿌리를 바꾸어나가게 하기 때문에 짧은 기간에도 분노, 우울, 불안, 갈등 등을 동시에 해결하게 한다고 하 였다. 이재기[47]는 마음수련명상 1단계 과정을 통해 우 주마음이 인간마음에 가려 있었음을 알게 되고 원래 깨 쳐 있었다는 것을 순간적으로 깨닫게 되는데, 실제 생 활로 돌아가면 스스로 깨달았다는 것에 대한 의구심이 일어나기도 하지만 본래 마음자리를 알았기 때문에 편 안한 마음으로 삶을 살 수 있는 기틀마련이 된다고 하 였다.

이러한 명상의 잇점을 고찰해 볼 때 스트레스 상황으 로 인한 신체적 건강 및 정신적 건강에 문제가 발생한 이후의 중재보다는 일상생활에서 스트레스를 예방하고 보완대체요법의 하나로서 임상에서 질병의 치료에 도 입함으로서 치료적 접근모델이 될 수 있음을 시사한다.

한편 본 연구에서 마음수련명상의 지속기간에 따른 정신건강의 차이비교에서 정신건강과 편집증을 제외한 8 개 하위영역(신체화, 강박증, 대인예민성, 우울, 불안, 적대감, 공포불안, 정신증)에서 유의한 차이가 있는 것 으로 나타났다. 즉 8개 영역에서 지속기간이 상대적으 로 오래된 대상자군이 지속기간 1-3년 미만인 군보다 전체 정신건강 및 8 개의 하부 영역별 점수가 낮게 나타 났다. 또한 지속적 명상군과 단기 명상군을 비교했을 때 단기명상군의 사전점수보다 지속적 명상군의 전체 정신건강 점수 및 하부영역별 점수가 낮아 장기간의 마 음수련 명상이 정신건강에 있어 긍정적인 변화를 유도 함을 알 수 있었다.

이러한 연구결과는 Manocha 등이 장기 요가명상군 이 일반인군보다 정신건강 점수가 높으며 명상이 일차 정신건강 예방에 매우 가치가 있다고 보고한 선행연구 [48] 결과처럼 지속적 명상이 정신건강 예방측면에서 아주 효과적임을 시사한다.

마음수련명상을 장기간 지속적으로 하는 경우 정신 건강에 효과가 있는 것으로 나타난 것은 마음수련명상 은 무언가를 내 것으로 하기위한 개체의식을 완전하게 버리는 '나없음'을 전제로 하여[18] 일체의 인간마음을 지속적으로 버리게 된다. 이러한 일련의 반복을 통해 본인의 사고방식이 전환되었다는 것을 스스로 보고 알 게 되고, 생활 속에서 꾸준히 비우려고 노력하게 된다.
이러한 과정에서 현실에 만족하게 되고, 개인에게 다가 오는 다양한 상황들을 항상 긍정적인 자세로 대처하는 능력을 갖게 되기 때문이다.

수행기간에 따른 명상 중재 후의 효과차이 분석[9]에 서 4 주 프로그램의 경우 우울, 불안, 부적정서를 유의 미하게 감소시키지 못했고, 12 주 프로그램은 8주보다 사후와 추수검사까지 효과성이 큰 것으로 나타났다. 장 현갑 등[37]은 스트레스 장면에 노출 시 효과가 발생하 기 위해서는 적어도 6 주 이상 프로그램을 수행해야 한 다는 주장하고 있다. 또한 명상과 침 치료의 기간이 경 과함에 따라 이전에 비해 외부자극을 잘 수용하고 이겨 내며 마음 다스리기를 한다는 선행연구[49] 결과들을 볼 때 장기 수련을 통해 지속적인 효과를 기대할 수 있 음을 짐작할 수 있다.

그러나 다도명상을 6 개월 이상 실시한 수련자와 비 수련자를 대상으로 한 연구[50]에서 심리척도를 이용한 불안검사에는 유의한 차이가 없었다. 그런데, 사례연구 에서 “급한 성격이 누그러짐", "모든 사물을 볼 때 여유 로와짐” 등을 보고하였으며, 심박변이도 검사결과 교감 신경계의 활성화를 억제하고 부교감신경을 활성화시킴 으로써 신체를 안정된 상태로 하여 스트레스에 대한 저 항력을 증가시키고 정신건강에 긍정적인 영향을 부여 한다는 결과를 고려할 때 장기간 명상의 효과를 측정할 때는 다양한 측정도구를 이용한 실험설계를 할 필요가 있겠다.

결론적으로 현대인의 정신건강에 영향을 미치는 스 트레스라는 위협적 상황과 그로 인한 부정적인 신체적, 정신적 변화에 대해 대처하는 능력이 요구되는바, 이는 명상훈련을 통해 향상될 것으로 생각된다. 장현갑의 주 장[51]처럼 명상을 규칙적으로 실천하면 스트레스 대처 에 매우 효과적인 자기조절 기법이 될 수 있지만 명상 이 스트레스 대처에 보다 유용하기 위해서는 실천자 자 신이 명상의 효과에 대한 확고한 믿음과 계속적인 실천 노력이 무엇보다 선행되어야 하겠다.

다른 전문직보다도 교사의 경우 학교의 기능과 교사 의 역할이 더욱 더 커지고 있는 만큼 학생들에게 제공 되는 교육의 질 또한 중요하다. 따라서 교사의 정신건 강은 작게는 학생의 발전, 더 나아가서는 국가발전에 
중요한 사안이 될 만큼 중요하므로 평소에 정신건강에 대한 예방책이 필요하다. 본 연구를 통하여 마음수련명 상은 다른 명상중재와 같이 심리적 디스트레스 감소시 키고 정신건강 유지 및 증진에 효과가 있는 것으로 나 타나 임상이나 지역사회에서 단기 또는 장기 정신건강 프로그램의 적용 가능성을 확인하였다.

본 연구의 제한점은 마음수련 명상에 참여한 일부 교 사만을 대상으로 하였으므로 본 연구결과를 일반화하 기에는 무리가 있다. 향후 후속 보완연구를 위한 제언 은 다음과 같다.

1. 건강인과 비 건강인의 비교실험을 통한 후속연구 가 필요하다.

2. 분석에 있어 양적분석 뿐 아니라 사례연구와 같은 질적 연구결과의 제시를 통해 보다 더 정확한 효 과의 분석이 필요하다.

3. 회기를 달리한 실험연구의 반복을 통해 기간에 따 른 차별화된 프로그램의 개발과 적용이 요구된다.

\section{참 고 문 헌}

[1] J. A. Moriana and J. Herruzo, "Stress and Burnout in teachers," International Journal of Clinical and Health Psychology, Vol.4, pp.597-621, 2004.

[2] 안귀여루, "직무스트레스와 보상이 기혼 여교사 의 적응에 미치는 영향”, 스트레스 연구, 제 16 권, 제3호, pp.241-249, 2008.

[3] 김미정, 이영순, “부적응적 완벽성 감소를 위한 인 지행동적 집단상담이 교사의 우울과 자기효능감 에 미치는 효과”, 동서정신과학, 제 6 권, 제 2 호, pp.281-302, 2003.

[4] F. Clemente, M. Israel, J. C. Adolfo, and M. Emilio, 'Reducing teachers' psychological distress through a mindfulness training program," The Spanish Journal of Psychology, Vol.13, No.2, pp.655-666, 2010.

[5] 김윤희, 이광자, 유숙자, 이소우, 김소야쟈, 정신간 호특론, 수문사, 2001.
[6] 김지수, 이승범, “홀리스틱적 기반을 둔 명상 호흡 법이 정신건강 및 스트레스 수준에 미치는 효과”, 홀리스틱 교육연구, 제13권, 제3호, pp.71-86, 2009.

[7] 나윤길, 마음수련 명상 및 성격유형별 심상훈련이 청소년 정신건강에 미치는 영향, 부산대학교 박 사학위논문, 2010.

[8] 박상규, "감정표현에 기반을 둔 명상프로그램이 대학생의 정신건강에 미치는 효과”, 한국심리학 회지; 건강, 제13권, 제4호, pp.995-1007, 2008.

[9] 배재홍, "수행기간에 따라 K-MBSR 프로그램이 대학생의 정서반응성에 미치는 영향”, 한국콘텐 츠학회논문지, 제10권, 제11호, pp.198-208, 2010.

[10] 대한보완통합의학회, 통합의학, 도서출판 한미의 학, 2012.

[11] 허동규, "명상 프로그램이 노인의 스트레스 반응 감소에 미치는 영향”, 한국콘텐츠학회논문지, 제9 권, 제3호, pp.232-240, 2009.

[12] 최연자, "오중유식과의 명상요법이 간호학생의 정신건강상태에 미치는 효과”, 정신간호학회지, 제15권, 제2호, pp.127-135, 2006.

[13] 우명, 이세상 살지말고 영원한 행복의 나라가서 살자, 참 출판사, 2011.

[14] 김미한, “명상캠프 프로그램이 아동 및 청소년의 우울, 불안, 자아존중감에 미치는 효과비교”, 한국 콘텐츠학회논문지, 제12권, 제4호, pp.338-348, 2012.

[15] 안이환, "마음수련 훈련과 아동의 상황불안", 인 문학논총, 제11권, 제2호, pp.215-233, 2006.

[16] http://taeguskh@Korea.kr

[17] 김정호, "위빠싸나 명상의 심리학적 고찰", 사회 과학연구, 제4권, pp.35-60, 1996.

[18] 정동명, 이상률, "마음수련의 원리와 심신의학 효과분석”, 한국정신과학학회지, 제 5 권, 제 2 호, pp.37-48, 2001.

[19] 정준용, 마음수련 명상이 홧병증상과 정신건강 상태, 자존감, 대처방식에 미치는 효과, 명지대학 교 석사학위논문, 2006. 
[20] 전진경, 박점희, "마음수련이 스트레스와 직무만 족도에 미치는 영향”, 경북간호과학지, 제 8 권, 제 1 호, pp.91-103, 2004.

[21] 최경숙, 이영순, 천성문, "마음수련이 신경증적 중학생의 분노와 불안에 미치는 효과”, 인문학논 총, 제11권, 제1호, pp.75-101, 2006.

[22] 박미란, 마음수련 프로그램이 아동의 불안에 미 치는 효과, 부산교육대학교 석사학위논문, 2006.

[23] 이인수, 김지희, "마음수련 명상이 교사의 불안, 자아존중감 및 자아실현에 미치는 효과”, 한국산 학기술학회논문지, 제 12 권, 제 12 호, pp.5722-5730, 2011.

[24] 이석기, 마음수련 명상 프로그램이 중고등학생 의 자아존중감에 미치는 영향:: 마음수련 청소년 캠프를 중심으로, 한국교원대학교 석사학위논문, 2011.

[25] 곽재용, "마음수련을 통한 초등학생의 인성지 도”, 초등교육연구, 제15권, pp.151-225, 2005.

[26] 이우경, 중년기 여성의 스트레스, 마음챙김, 자기 -자애, 정서적 안녕감간의 관계 구조분석과 마음 챙김 증진 프로그램의 효과연구, 이화여자대학교 박사학위논문, 2008.

[27] 최연자, "명상요법이 간호학생의 자아존중감과 사회적 회피, 불안에 미치는 효과”, 정신건강간호 학회지, 제19권, 제2호, pp.133-142, 2010.

[28] 장선주, 하양숙, “국선도를 활용한 명상프로그램 이 정신과 입원환자의 스트레스 반응, 불안 및 자 아존중감에 미치는 효과”, 정신간호학회지, 제 17 권, 제3호, pp.302-310, 2008.

[29] N. Ivan, and F. K. Karlijn, "Effects of Mindfulness-based stress reduction intervention on psychological well-being and quality of life: Is increased Mindfulness indeed the mechanism?," Ann Behav Med, Vol.35, pp.331-340, 2008.

[30] 정인순, 명상 프로그램이 노인의 정신건강에 미 치는 효과성 검증, 동의대학교 석사학위논문, 2011.

[31] 배재홍, 장현갑, “한국형 마음챙김 명상에 기반
한 스트레스 감소 프로그램이 대학생의 정서반응 성에 미치는 영향”, 한국심리학회지: 건강, 제 11 권, 제4호, pp.673-688, 2006.

[32] http://www.maum.org/introduce/010301.asp

[33] L. R. Derogatis, R. S. Lipman, and L. Covi "SCL-90:An outpatient psychiatric rating scale," Psychopharm Bull, Vol.9, pp.13-27, 1973.

[34] 김재환, 김광일, 원호택, "정신과 외래환자의 간 이정신진단검사 $(\mathrm{SCL}-90-\mathrm{R})$ 의 진단별 특성”, 정 신건강연구, 제1집, pp.150-168, 1983.

[35] 배행자, "알코올 중독과 비알코올 중독 가정 중1 학생의 정신건강”, 정신간호학회지, 제 14 권, 제 3 호, pp.240-249, 2005.

[36] 정혜선, 송은주, “군 집단상담 프로그램이 병사 의 정신건강, 자아존중감 및 삶의 질에 미치는 효 과”, 정신간호학회지, 제 17 권, 제 4 호, pp.353-362, 2008.

[37] 장현갑, 김정모, 배재홍, “한국형 마음챙김 명상 에 기반한 스트레스 감소 프로그램의 개발과 $\mathrm{SCL}-90-\mathrm{R}$ 로 본 효과성 검증”, 한국심리학회지; 건강, 제 12 권, 제4호, pp.833-850, 2007.

[38] 최연자, "명상요법이 간호학생의 사회불안 감소 에 미치는 효과” 정신간호학회지, 제 16 권, 제 3 호, pp.242-249, 2007.

[39] 최연자, "불교의 사심사관적 명상요법이 간호학 생의 우울감소에 미치는 효과”, 정신간호학회지, 제10권, 제2호, pp.229-240, 2001.

[40] J. M. G. Williams, J. D. Teasdale, Z. V. Segal, and J. Soulsby, "Mindfulness-based cognitive therapy reduces over general autobiographical memory in formerly depressed patients," Journal of Abnormal Psychology, Vol.109, No.1, pp.150-155, 2000.

[41] 이봉건, "한국형 마음챙김 명상이 대학생의 우울 증상, 마음챙김 수준 및 몰입수준에 미치는 효과”, 한국심리학회지; 임상, 제27권, 제1호, pp.333-345, 2008.

[42] L. E. Carlson, M, Speca, K. D. Patel, and E. 
Goodey, "Minfulness-based stress reduction in relation to quality of life, mood, symptoms of stress, and immune parameters in breast and prostate cancer outpatients," Psychosom Med, Vol.65, pp.571-581, 2003.

[43] C. A. Lengacher, V. Johnson-mallard, and J. Post-white, "Randomized controlled trial of mindfulness-based stress reduction(MBSR) for survivors of breast cancer," Psycho-Oncology, 2009; Epub February 20. DOI:10.1002/pon.1529, 2009.

[44] 박미정, 권기남, “그림책을 활용한 명상 프로그램 이 유아의 공격성 감소에 미치는 영향”, 한국지역 사회생활과학회지, 제21권, 제 1 호, pp.125-138, 2010.

[45] 김유미, "명상기반 인지행동 프로그램이 아동의 정서안정도에 미치는 효과”, 아동교육, 제 18 권, 제 2호, pp.105-115, 2009.

[46] A. J. Zautra, M. C. Davis, P. Finan, A. Kratz, P. Nicassio, B. Parrish, J. W. Reich, and H. Tennen, "Comparison of cognitive behavioral and mindfulness meditation interventions on adaptation to rheumatoid arthritis for patients with and without history of recurrent depression," Journal of Consulting and Clinical Psychology, Vol.76, No.3, pp.408-421, 2008.

[47] 이재기, “하나되는 마음수련법”, 한국정신과학회 학술대회논문집, 제10권, pp.39-45, 1999.

[48] R. Manocha, D. Black, and L. Wilson, "Quality of life and functional health status long-term mediators," Evid Based Complement Alternat Med,. 2012;2012:350674. Epub 2012 May 7, Free PMC Article.

[49] 강현선, 김자영, 이진환, 성우용, "신체증상을 주 증상으로 호소하는 우울증 환자에 대한 침치료와 명상의 결합을 응용한 치험 2례", 동의신경정신 과학회지, 제19권, 제2호, pp.241-250, 2008.

[50] 이화순, 다도명상이 정신건강에 미치는 영향, 계 명대학교 석사학위논문, 2006.
[51] 장현갑, "명상의 심리학적 개관-명상의 유형과 정신생리학적 특징”, 한국심리학회지; 건강, 제 1 권, 제1호, pp.15-33, 1996.

\section{저 자 소 개}

이 인 수(In-Soo Lee)

정회원

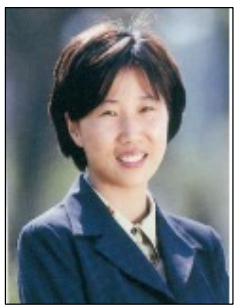

- 1987년 2월 : 연세대학교 간호학 과(간호학사)

- 1991년 8월 : 연세대학교 보건간 호학과(보건학 석사)

- 2008년 2월 : 충북대학교 의료정 보및관리학과(의학박사 수료)

- 1995년 8월 현재 : 한국교통 대학교 응급구조학과 교수

<관심분야> : 스트레스, 정신건강

\section{오 진 환(Jin-Hwan $\mathrm{Oh})$}

정회원

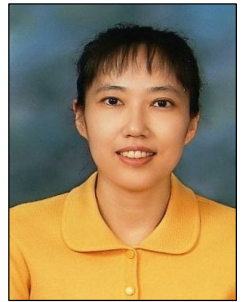

- 1988년 2월 : 한양대학교 간호학 과(간호학사)

- 2002년 8월 : 한양대학교 간호학 과(간호학 석사)

- 2006년 2월 : 한양대학교 간호학 과(간호학 박사)

- 2011년 8월 현재 : 수원과학대학 간호과 조교수 <관심분야> : 스트레스, 정신건강

\section{권 인 숙(In-Sook Kwon)}

정회원

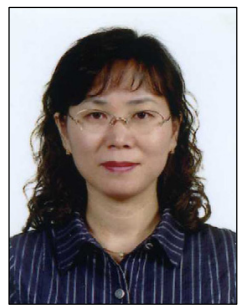

- 1985년 2월 : 연세대학교 간호학 과(간호학사)

- 1991년 8월 : 연세대학교 보건간 호학과(보건학 석사)

- 2007년 2월 : 연세대학교 간호대 학(간호학박사)

- 1985년 3월 현재 : 이화여자대학교부속고등학교 보건교사

<관심분야> : 학교보건, 정신건강 